\title{
O PIVÔ GEOGRÁFICO DA HISTÓRIA
}

Conferência lida na Royal Geographical Society, em 25 de janeiro de 1904. Texto publicado nф

The Geographical Journal, Vol. 23, número IV, abril de 1904, pp. 421 - 37

Halford J. Mackinder*

Tradução de Fabrício Vasselai**

Quando historiadores no futuro remoto vierem a olhar novamente sobre o grupo de séculos pelos quais estamos passando agora, e enxergando-nos em perspectiva, como hoje vemos as dinastias egípcias, pode muito bem ser que descrevam os últimos 400 anos como a época Colombina e digam que ela acabou logo após o ano 1900. Ultimamente, tem sido lugar comum falar sobre a exploração geográfica como quase encerrada, e se reconhece que a geografia deva ser direcionada para o propósito da investigação intensiva e da síntese filosófica. Em 400 anos o contorno do mapa do mundo foi completado com aproximada precisão, e mesmo nas regiões polares as viagens de Nansen e de Scott reduziram muitíssimo a última possibilidade de descobertas dramáticas. Mas a abertura do vigésimo século é tomada como o fim de uma grande época histórica, não apenas em decorrência desse feito, por mais importante que possa ser. O missionário, o conquistador, o fazendeiro, o mineiro e, recentemente, o engenheiro, seguiram tão de perto os passos dos viajantes que o mundo, nas suas fronteiras mais remotas, mal fora descoberto quando já podemos fazer a crônica de sua apropriação política virtualmente completa. $\mathrm{Na}$ Europa, América do Norte, América do Sul, África e Australásia, mal restou alguma região para ser alvo de reivindicação de propriedade, exceto como resultado de uma guerra entre poderes civilizados e semicivilizados. Mesmo na Ásia, estamos provavelmente presenciando os últimos movimentos do jogo iniciado pelos cavaleiros de
Yermak, o Cossaco, e pelos marinheiros de Vasco da Gama. Genericamente falando, podemos contrastar a época Colombina com a idade que a precedeu ao descrever as características essenciais da primeira como a expansão da Europa contra resistências quase insignificantes, enquanto a Cristandade medieval estava encurralada em uma região estreita e ameaçada pelo barbarismo externo. De hoje em diante, na idade pósColombina, devemos novamente ter de lidar com um sistema político fechado, e no entanto será um de escopo mundial. Toda explosão de forças sociais, no lugar de ser dissipada em um circuito ao redor, de espaço desconhecido e caos bárbaro, será fortemente reecoada desde as longínquas partes do globo, e por isso os fracos elementos no organismo político e econômico do mundo serão em consequência destroçados. Há uma ampla diferença do efeito causado pela queda de uma granada em uma terraplanagem e sua queda em meio aos espaços fechados e às rígidas estruturas de uma grande construção ou embarcação. Provavelmente alguma semiconsciência desse fato é que está finalmente desviando grande parte da atenção de estadistas em todas as partes do mundo da expansão territorial para a luta pela relativa eficiência.

Parece-me, portanto, que na presente década estamos pela primeira vez em uma posição de tentar, com algum grau de completude, uma correlação entre as generalizações geográfica e histórica mais amplas. Pela primeira vez podemos perceber algo das reais proporções

** doutorando em Ciência Política do Departamento de Ciência Política da Universidade de São Paulo - e-mail: fabriciovasselai@usp.br 
de características e de eventos do mundo como um todo, e perseguir uma fórmula que expresse certos aspectos, em algum grau, da causalidade geográfica sobre a história universal. Se tivermos sorte, essa fórmula teria um valor prático de colocar em perspectiva algumas das forças competidoras na atual política internacional. A frase familiar sobre a marcha imperial para oeste é uma tentativa empírica e fragmentária desse tipo. Proponho esta noite descrever tais características físicas do mundo que acredito venham sendo, em muito, coercitivas da ação humana, e apresentar algumas das fases principais da história como organicamente conectadas com essas características, mesmo em idades em que eram desconhecidas pela Geografia. Meu propósito não será discutir a influência desta ou daquela classe de características, ou, ainda, fazer um estudo de geografia regional, mas sim mostrar a história humana como parte da vida do organismo mundial. Reconheço que posso alcançar apenas um aspecto da verdade e não tenho nenhum desejo de dispersar-me para um excessivo materialismo. É o homem e não a natureza que tem a iniciativa, mas a natureza em grande medida controla. Minha preocupação é com o controle físico geral, mais do que com as causas da história universal. É óbvio que apenas uma primeira aproximação com a verdade pode ser esperada. Devo ser humilde perante meus críticos.

O falecido professor Freeman sustentava que a única história que conta é aquela das raças mediterrâneas e europeias. Em certo sentido, claro, isso é verdade, pois foi entre essas raças que se originaram as ideias que fizeram os herdeiros de Grécia e de Roma dominantes em todo o mundo. Em outro sentido, e muito importante, contudo, tal limitação tem um efeito de sujeitar o pensamento. As idéias que vão formar uma nação, em oposição a uma mera multidão de animais humanos, usualmente são aceitas sob a pressão de uma tribulação comum e sob a necessidade comum de resistência a uma força externa. A ideia de Inglaterra foi forjada na heptarquia pelos conquistadores Dinamarqueses e Normandos; a ideia de França foi forçada pelos hunos de Chalons frente aos competidores Francos, Góticos e Romanos e também na Guerra dos Cem Anos com a Inglaterra; a ideia de Cristandade nasceu das perseguições romanas e amadureceu através das Cruzadas; a ideia de Estados Unidos só foi aceita, e o patriotismo local abatido, apenas na longa Guerra de Independência; a ideia de Império Germânico foi relutantemente adotada na Alemanha do Sul apenas depois da contenda contra a França em união à Alemanha do Norte. O que eu poderia descrever como a concepção literária da história, concentrando atenção nas ideias e nas civilizações que seriam seus produtos, perderia de vista os movimentos mais elementares cuja pressão é comumente a causa de que existam os esforços em que se nutrem as grandes ideias. Uma personalidade repulsiva desempenha uma função social valiosa ao unir seus inimigos e foi, justamente sob a pressão do barbarismo estrangeiro, que a Europa atingiu sua civilização. Peço a vocês, portanto, para olharem por um momento à Europa e à história europeia como subordinadas à Ásia e à história asiática, uma vez que a civilização europeia é, em um sentido muito real, o produto da luta secular contra a invasão asiática.

O mais notável contraste no mapa político da Europa moderna é aquele representado pela vasta área da Rússia ocupando metade do continente e o grupo de territórios menores ocupados pelas potências a oeste. De um ponto de vista físico, há, é claro, um contraste equivalente entre as ininterruptas terras baixas do leste e o rico complexo de montanhas e vales, ilhas e penínsulas, que juntos formam o restante desta parte do mundo. À primeira vista pareceria que nesses fatos conhecidos temos uma correlação entre meio natural e organização política tão óbvia que dificilmente valeria a pena descrevêla, especialmente quando notamos que através da planície russa um frio inverno se opõe a um quente verão, então se mostrando adicionalmente uniforme as condições de existência humana. Ainda uma série de mapas históricos, tais como esses contidos no Atlas Oxford, revelará o fato de que a grande coincidência entre a Rússia europeia e a planície do leste europeu não é própria apenas dos últimos cem anos ou mais, mas que em todos os tempos havia persistente reafirmação de uma outra tendência bem diferente no agrupamento 
político. Dois grupos de Estados usualmente dividiram o país em sistemas políticos setentrional e meridional. O fato é que o mapa ortográfico não expressa o contraste físico particular que até pouco tempo controlou o movimento e o estabelecimento humanos na Rússia. Quando a cortina da neve de inverno se desvanece para o norte na vasta extensão da planície, ela é seguida por chuvas cujo máximo ocorre em maio e junho próximo ao Mar Negro, mas que se postergam até julho e agosto perto dos mares Báltico e Branco. No sul, o fim do verão é um período de seca. Como consequência desse regime climático, o norte e o noroeste eram cobertos por florestas interrompidas apenas por pântanos, considerando que o sul e o sudeste eram de uma estepe gramínea ilimitada, com árvores apenas ao longo dos rios. A linha separando as duas regiões corria diagonalmente em direção ao nordeste desde o extremo norte dos Cárpatos até um ponto nos Urais, situado mais perto de sua extremidade meridional do que da setentrional

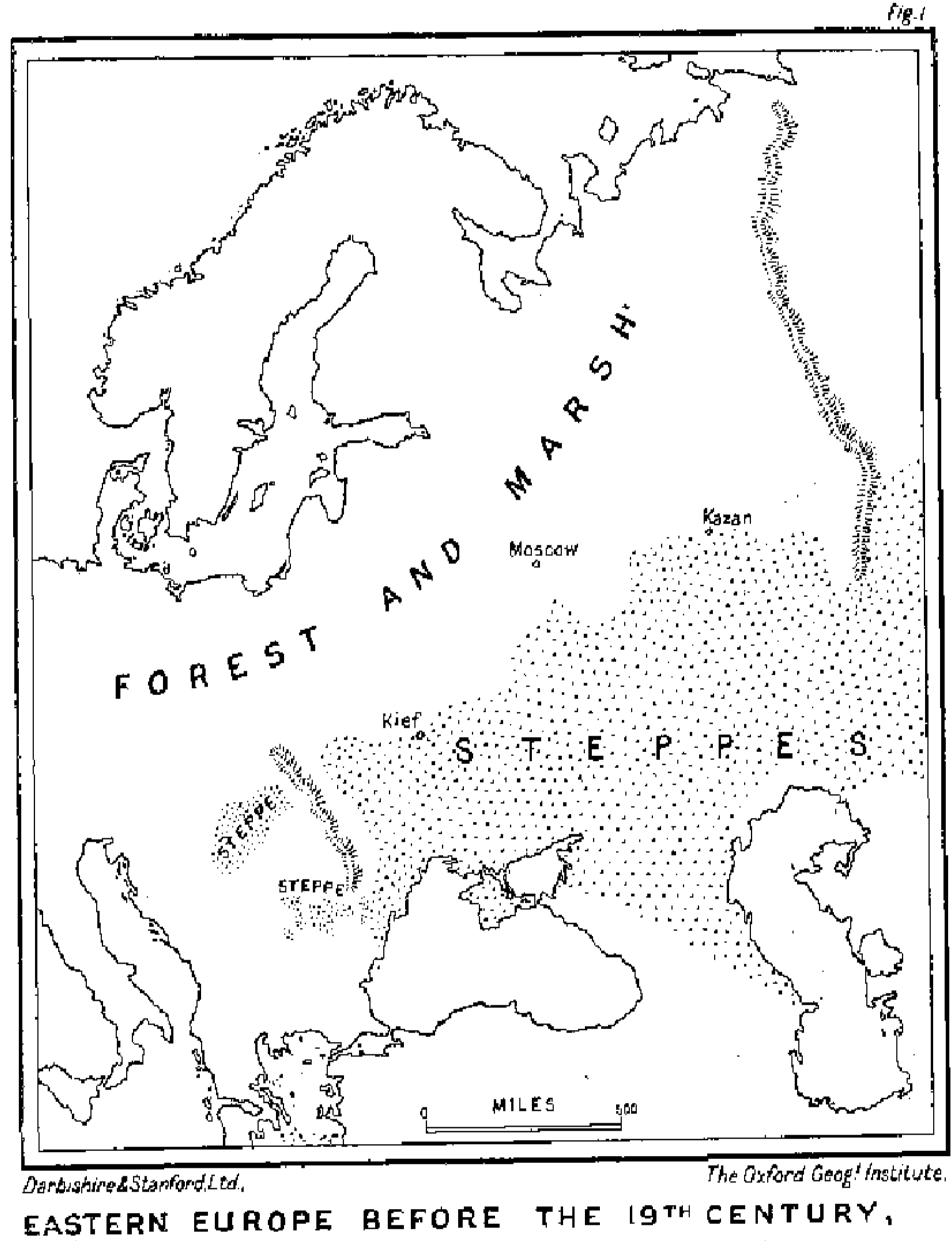

(AFTEA DRUDE IN BERGHAUS" PHYSIGAL atLAS.) 
Moscou está um pouco ao norte dessa linha ou, em outras palavras, do lado em que estão as florestas. Fora da Rússia, o limite das grandes florestas correu para oeste exatamente quase exatamente através do centro do istmo europeu, o qual tem 1300 quilômetros entre os mares Báltico e Negro. Além disso, na Europa peninsular, as florestas estendem-se através das planícies da Alemanha ao norte, enquanto as terras da estepe ao sul contornaram o grande bastião transilvânico dos Cárpatos e se estenderam até o Danúbio, através do que são hoje os milharais da Romênia até os Portões de Ferro. Uma área isolada de estepes, conhecida localmente como Puszta, agora largamente cultivada, ocupa a planície da Hungria, circundada pela borda florestal das montanhas dos Cárpatos e dos Alpes. Em todo o oeste da Rússia, salvo o extremo norte, a poda das florestas, a drenagem dos pântanos e o preparo do solo das estepes têm recentemente unificado o caráter da paisagem e, em grande medida, obliteraram uma distinção que antigamente exercia um grande efeito coercitivo sobre a humanidade.

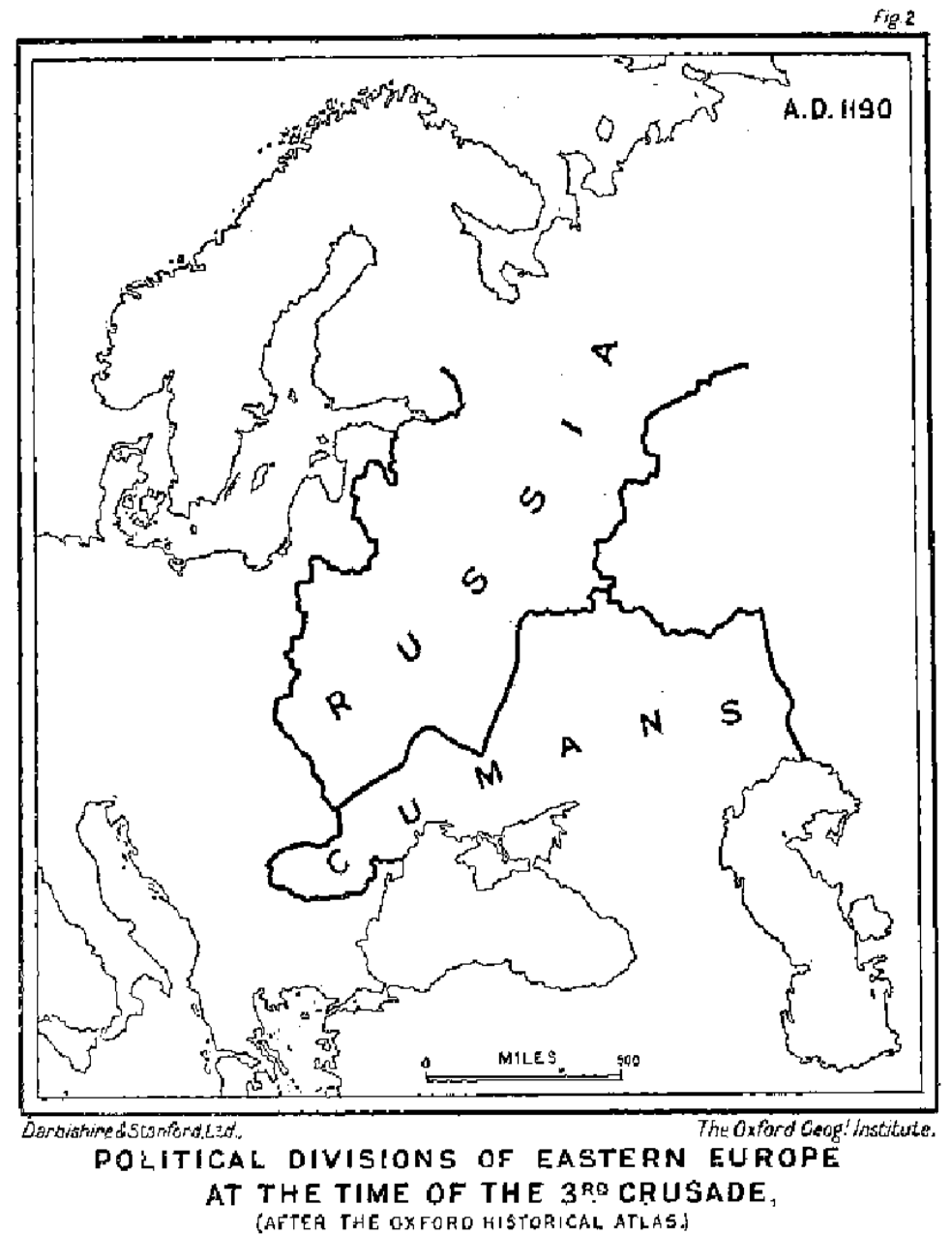


As Rússia e Polônia de antigamente estavam estabelecidas inteiramente nas clareiras da floresta. Através das estepes, pelo contrário, em todos os séculos do quinto ao décimo sexto veio, dos lugares desconhecidos e remotos da Ásia e passando pelo portão de entrada formado pelas montanhas Urais e o mar Cáspio, uma notável sucessão de povos nômades turanianos - hunos, ávaros, búlgaros, magiares, khazares, patzinaks, cumans, mongóis e kalmuks. Sob Átila, os hunos se estabeleceram na parte central da Puszta, nos confins das estepes danubianas, e dali desferiram golpes em direção ao norte, a oeste e ao sul contra os povos estabelecidos na Europa. Uma grande parte da história moderna poderia ser escrita como um comentário sobre as mudanças direta ou indiretamente advindas dessas incursões. Os anglos e os saxões, é bem possível, foram então levados a atravessar os mares para fundar a Inglaterra nas ilhas britânicas. Os francos, os godos e os provinciais romanos foram compelidos, pela primeira vez, a lutar ombro a ombro no campo de batalha de Chalons, fazendo causa comum contra os asiáticos que, assim, estavam inconscientemente soldando a moderna França. Veneza foi fundada

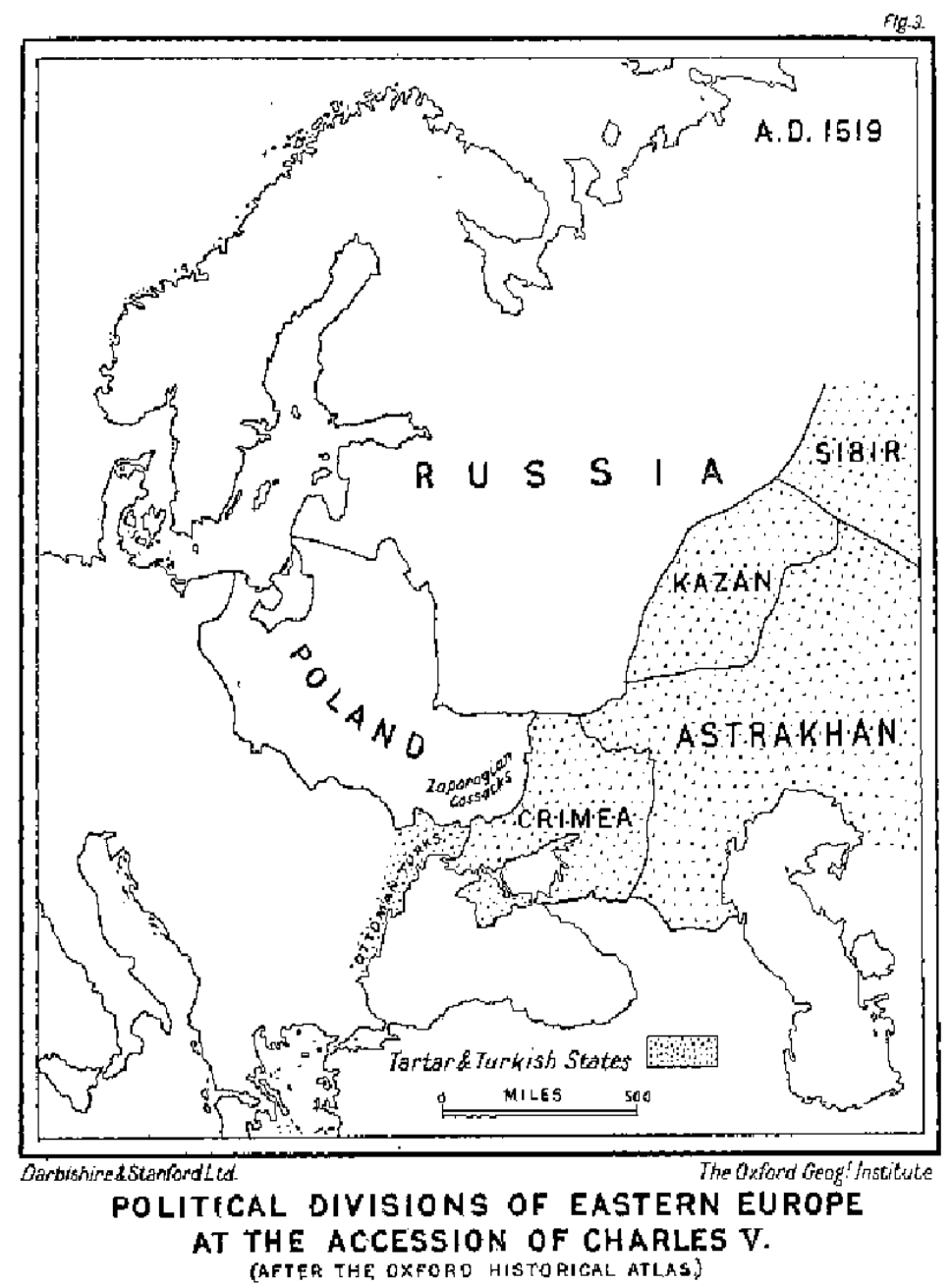


pela destruição de Aquileia e Pádua; e mesmo o Papado deveu um prestígio decisivo à bem sucedida mediação do Papa Leo perante Átila, em Milão. Essa foi a colheita de resultados produzida por uma nuvem de cavaleiros cruéis e sem ideais varrendo a planície desimpedida - um sopro, como se fosse, do grande martelo asiático golpeando livremente através do espaço vago. Os hunos foram seguidos pelos ávaros. Foi por causa de uma marcha para criar fronteira contra esses que a Áustria foi fundada e Viena fortificada, como resultado das campanhas de Carlos Magno. Os magiares vieram em seguida e, fazendo incessantes incursões desde sua base na Hungria, aumentaram a significância do posto avançado que era a Áustria, estendendo o foco político desde a Alemanha até o limite do reino. Os búlgaros estabeleceram uma casta dominante ao sul do Danúbio, e deixaram seu nome no mapa ainda que seu idioma tenha se rendido para o dos seus súditos eslavos. Talvez a mais longa e a mais efetiva ocupação da estepe russa propriamente dita tenha sido a dos cazares, que eram contemporâneos do grande movimento sarraceno: os geógrafos árabes conheciam o Cáspio como mar do Cazares. No final, contudo, novas hordas chegaram da Mongólia e por dois séculos a Rússia das florestas setentrionais foi tributária dos khanes mongóis de Kipchak, ou "o Estepe", e dessa forma o desenvolvimento russo foi ao mesmo tempo atrasado e distorcido quando o resto da Europa avançava rapidamente.

Deve-se notar que os rios correndo da floresta para os mares Negro e Cáspio cruzam toda a amplitude do caminho seguido pelos nômades pelas terras de estepe, e que de tempos em tempos houve ao longo dos cursos desses rios movimentos transitórios dispostos em ângulo reto em relação ao movimento dos cavaleiros. Deste modo os missionários da cristandade grega ascenderam o Dnieper até Kiev, assim como anteriormente os varangianos nórdicos haviam descido o mesmo rio em seu caminho para Constantinopla. Ainda antes disso, os godos teutônicos aparecem por um momento no Dniester, tendo atravessado a Europa desde as costas do Báltico na mesma direção sudeste. Mas esses são episódios passageiros que não invalidam a generalização. Durante mil anos uma série de povos cavaleiros que emergiu da Ásia através da ampla intermitência entre as montanhas Urais e o mar Cáspio cavalgou através dos espaços abertos da Rússia meridional e, na Hungria, eles desferiram o golpe crítico no próprio coração da península europeia, moldando assim a história dos grandes povos ao seu redor que se viam na necessidade de fazer-lhes frente: os russos, os alemães, os franceses, os italianos e os gregos bizantinos. Que tenham estimulado uma reação saudável e poderosa, no lugar de aplastar a oposição mediante generalizado despotismo, deveu-se ao fato de que a mobilidade de seu poder estava condicionada pelas estepes e necessariamente cessava nas florestas e nas montanhas circundantes.

Uma mobilidade de poder rival era a dos vikings em seus barcos. Descendo da Escandinávia até as costas da Europa, tanto setentrionais quanto meridionais, penetraram terra a dentro pelos rios. Mas o alcance de sua ação foi limitado, falando em termos gerais, porque foi efetivo apenas nas proximidades da água. Dessa forma os povos estabelecidos da Europa estavam presos entre duas pressões - aquela dos nômades asiáticos pelo leste e, nos outros três pontos cardinais, aquela dos piratas pelo mar. Por sua própria natureza, nenhuma dessas pressões foi esmagadora e ambas, por consequência, foram estimulantes. Vale a pena notar que a influência formativa dos escandinavos foi superada em importância apenas pela dos nômades, já que sob seus ataques ambas Inglaterra e França avançaram muito em seus caminhos em direção a unidades, enquanto a unidade da Itália foi quebrada por eles. Anteriormente, Roma havia mobilizado o poder de seus povos estabelecidos graças a suas estradas, mas essas estradas romanas entraram em decadência e não foram substituídas até o século dezoito.

É provável que mesmo a invasão huna não tenha sido de modo algum a primeira da série asiática. Os escitas, bebedores de leite de éguas, que figuram dos relatos de Homero e Heródoto, obviamente praticaram as mesmas artes da vida e eram provavelmente da mesma raça que os posteriores habitantes das estepes. O elemento celta nos nomes dos rios Don, Donets, Dnieper, Dniester e Danúbio podem possivelmente vaticinar 
a passagem de povos de hábitos similares, ainda que não de raça idêntica, mas não é inverossímil que os celtas tenham vindo meramente das florestas do norte como os godos e os varangianos fariam posteriormente. A grande cunha de populações, entretanto, a qual os antropólogos caracterizaram como braquicéfalos, e que se dirigiu a oeste desde a Ásia braquicéfala até a França, através da Europa central, é aparentemente uma intrusa entre as populações dolicocéfalas do norte, oeste e sul e muito provavelmente deriva da Ásia ${ }^{1}$.

O completo significado da influência asiática sobre a Europa não é discernível, no entanto, até que cheguemos às invasões mongóis do século XV; mas antes que analisemos os fatos que a elas se referem, é desejável deslocar da Europa nosso ponto de vista geográfico a fim de poder considerar o Velho Mundo em sua totalidade. É óbvio que, como as chuvas derivam-se do mar, o coração das massas de terra é provável que seja seco. Não nos surpreende, portanto, encontrar que dois terços de toda a população mundial está concentrada em áreas relativamente pequenas junto às margens do grande continente - na Europa, ao lado do oceano Atlântico; nas Índias e na China, ao lado dos oceanos Índico e Pacífico. Um vasto cinturão de terras quase inabitadas, por causa da quase total ausência de chuvas, estende-se, na figura do Saara, atravessando completamente o norte da África e entrando na Arábia. As Áfricas central e meridional estiveram quase tão completamente separadas da Europa e da Ásia ao longo de grande parte da história como estavam as Américas e a Austrália. De fato, a fronteira sul da Europa tem sido o Saara e não o Mediterrâneo, já que é o deserto que separa o homem branco do negro. A massa de terra contínua da Eurásia assim compreendida entre o oceano e o deserto mede 54,4 milhões de quilômetros quadrados, ou metade de toda a terra do globo se excluímos da contagem os desertos do Saara e da Arábia. Há muitos desertos isolados espalhados pela Ásia, da Síria e do nordeste da Pérsia até a Manchúria, mas nenhum vazio comparável ao do Saara. Por outro lado, a Eurásia é caracterizada por uma notável distribuição da drenagem de seus rios. Por toda uma imensa porção do centro e do norte, os rios têm sido praticamente inúteis para os propósitos de comunicação humana com o mundo exterior. O Volga, o Amu-Dária e o Sir Dária deságuam em lagos salgados; o Obi, o Ienissei e o Lena em oceanos congelados do norte.

Esses são seis dos maiores rios do mundo. Há muitos rios menores mas ainda assim de considerável importância na mesma área, como o Tarim e o Helmand que de modo similar falham em chegar ao oceano. Assim o coração da Eurásia, embora uma malha com pequenos retalhos de deserto, é em seu conjunto uma estepe fornecendo extensos pastos, ainda que escassos, e na qual há não poucas zonas regadas por rios, mas é inteiramente não penetrada por caminhos d'água advindos do oceano. Em outras palavras, temos nessa área imensa todas as condições para a manutenção de uma população esparsa, mas considerável no agregado, de nômades que montam cavalos e camelos. Seus domínios estão limitados ao norte por uma larga faixa de florestas e pântanos subárticos, na qual o clima é excessivamente rigoroso para o desenvolvimento dos assentamentos agrícolas, exceto nas extremidades leste e oeste. No leste as florestas estendem-se ao sul até a costa do Pacífico, nas terras do Amur e da Manchúria. Similarmente, no oeste, na Europa pré-histórica as florestas eram a vegetação predominante. Assim enquadradas pelo nordeste, norte e noroeste, as estepes se estendem continuamente por 6.400 quilômetros da Puszta da Hungria ao pequeno Gobi da Manchúria e, exceto em sua extremidade mais ocidental, não são atravessadas por rios que deságuem em um oceano acessível, já que não podemos considerar os esforços muito recentes de comercializar nas fozes do Obi e do Ienissei. Na Europa, Sibéria ocidental e Turquestão ocidental, as terras de estepe são baixas, chegando em alguns lugares a estar abaixo do nível do mar. Mais ao leste, na Mongólia, elas estendem-se sobre platôs; mas a passagem de um nível para o outro, sobre as despidas e sem declive faixas menores de terra árida, apresenta poucas dificuldades.

As hordas que finalmente caíram sobre a Europa no meio do século XIV reuniram suas primeiras forças a 4.800 quilômetros dali, nas altas estepes da Mongólia. Os estragos causados durantes alguns anos na Polônia, Silésia, Moravia, 
Hungria, Croácia e Sérvia não eram, no entanto, senão os mais remotos e transitórios resultados da grande agitação dos nômades do leste associados com o nome de Gengis Khan. Enquanto a Horda de Ouro ocupou a estepe de Kipchak, do mar de
Aral, através do intervalo entre os montes Urais e o mar Cáspio, até o pé dos Cárpatos, outra horda desceu a sudoeste entre o mar Cáspio e o Hindu Kush dentro da Pérsia, Mesopotâmia e inclusive dentro da Síria e fundou o domínio de Ilkan.

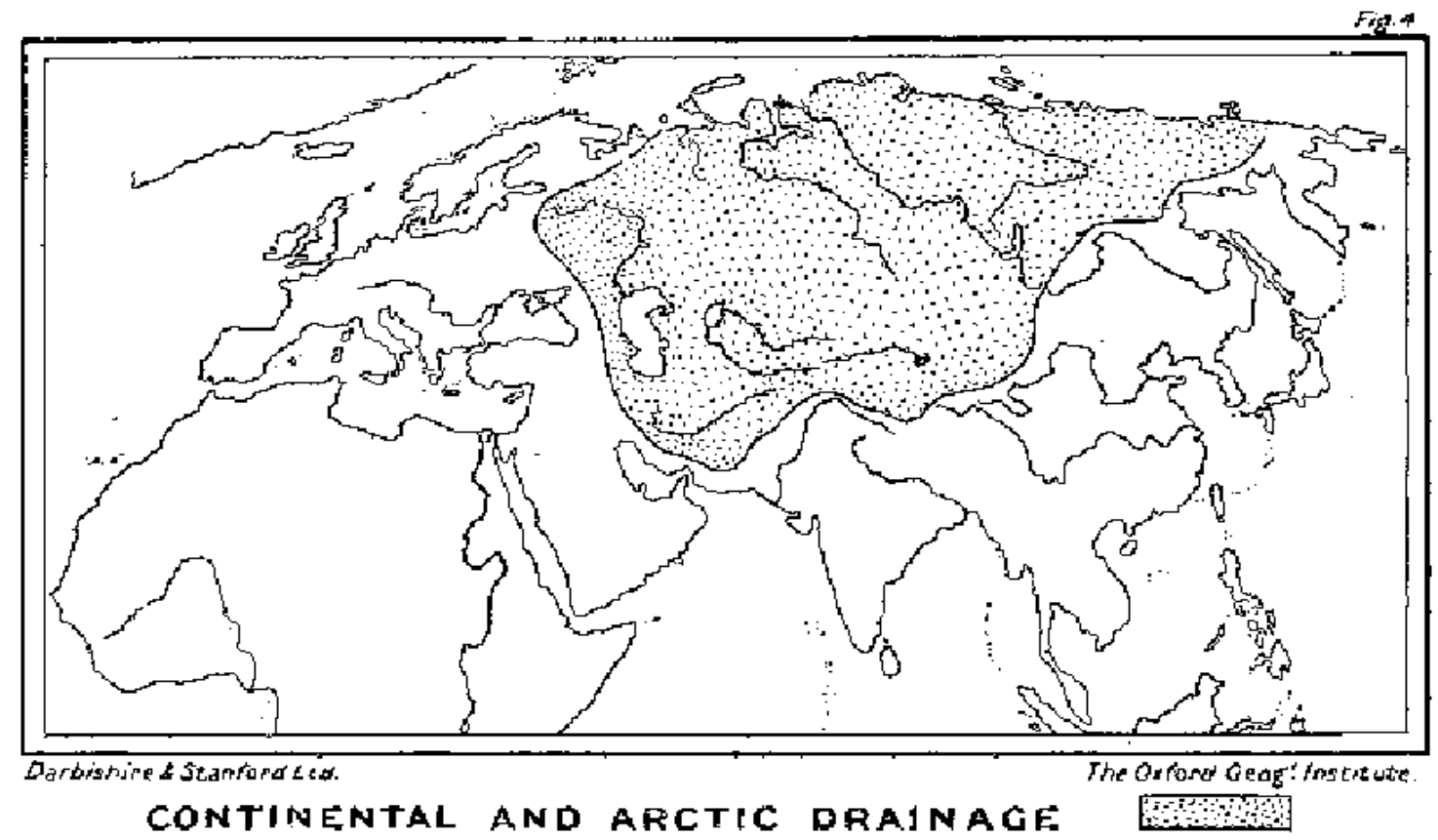

EQUAL AREA PROJEGTION

Uma terceira horda subsequentemente penetrou no norte da China, conquistando Catai. A Índia e Mangi, ou seja a China meridional, foram protegidas por algum tempo pela incomparável barreira do Tibet, cuja eficácia como tal talvez não haja similar no mundo, a não ser o deserto do Saara e o gelo polar. Mas posteriormente, nos dias de Marco Pólo no caso de Mangi, e nos de Tamerlão no caso da Índia, o obstáculo foi circundado. Assim aconteceu que nesse típico e bem lembrado caso, todas as margens do Velho Mundo cedo ou tarde sentiram a força expansiva do poder móbil originado nas estepes. Rússia, Pérsia, Índia e China foram convertidas em tributárias ou receberam dinastias mongóis. Até mesmo o poder incipiente dos turcos na Ásia Menor foi subjugado por meio século.
Como no caso da Europa, também em outras terras marginais da Eurásia há registros de invasões antigas. A China teve que se submeter mais de uma vez às conquistas que vinham do norte; a Índia muitas vezes às conquistas vindas do noroeste. No caso da Pérsia, contudo, ao menos um dos antigos invasores tem um significado especial na história da civilização Ocidental. Três ou quatro séculos antes dos mongóis, os turcos seljúcidas, emergindo da Ásia central, atravessaram por esse mesmo caminho uma imensa área de terra que poderíamos descrever como a dos cinco mares Cáspio, Negro, Mediterrâneo, Vermelho e Pérsico. Estabeleceram-se em Kerman, em Hamadã e na Ásia menor, e subverteram o domínio sarraceno em Bagdá e Damasco. E era pretensamente 
para punir o tratamento que esses dispensavam aos peregrinos cristãos em Jerusalém, que a Cristandade empreendeu a grande série de campanhas coletivamente conhecidas como as Cruzadas. Ainda que essas campanhas tenham falhado em seus objetivos imediatos, elas tanto agitaram e uniram a Europa que podemos considerá-las como o início da história moderna - outro notável exemplo de avanço europeu estimulado pela necessidade de reagir contra as pressões vindas do coração da Ásia.

A concepção de Eurásia a que chegamos desse modo é a de uma terra contínua, rodeada por gelo ao norte, pela água nas outras partes, medindo 54,4 milhões de metros quadrados, ou seja mais de três vezes a área da América do Norte; e cujo cento e norte com ao redor de 23,3 milhões de quilômetros quadrados medem mais do que o dobro da Europa, sem ter nenhum curso de água que chegue ao oceano, mas que por outro lado, e excetuando a zona dos bosques subárticos, são geralmente favoráveis para mobilidade dos homens montadores de cavalos e de camelos. Ao leste, sul e oeste desse heart-land, estão as regiões marginais, dispostas em umo vasto semicírculo acessível aos navegantes. De acordo com sua conformação física, essas regiões são em número de quatro, e não é pouca coisa que em geral elas coincidam respectivamente com as esferas das quatro grandes religiões - Budismo, Bramanismo, Maometismo e Cristianismo. As duas primeiras são as terras monçônicas, uma voltada para o Pacífico e a outra para o oceano Índico. A quarta é a Europa, regada pelas chuvas do Atlântico pelo oeste. Essas três, juntas, medindo menos de 18,1 milhões de quilômetros quadrados, têm mais de 1000 milhões de pessoas, ou seja dois terços da população mundial. A terceira região, coincidindo com a terra dos cinco mares, ou, como é mais comumente descrita, o Oriente Próximo, está em grande medida desprovida de umidade pela proximidade com a África e, exceto nos oásis, está por conseguinte escassamente povoada. Em certa medida, compartilha das características tanto da faixa marginal quanto da área central da Eurásia. Está em geral desprovida de florestas, pontuada por desertos, e está assim propícia às operações dos nômades. Predominantemente, porém, tem caráter de faixa marginal, já que os golfos marítimos e os rios oceânicos fazem dessa região aberta ao alcance do poder marítimo e permitem que esse mesmo poder se exerça desde ali. Como consequência, periodicamente ao longo da história, tem havido nessa região impérios essencialmente do tipo que se situa nas margens, baseados nas populações agrícolas dos grandes oásis da Babilônia e do Egito e em livre comunicação marítima com os mundos civilizados do Mediterrâneo e das Índias. Mas, como deveríamos esperar, esses impérios têm sido objeto de uma série de revoluções sem paralelo, algumas graças às incursões escitas, turcas e mongóis desde a Ásia central, outras graças ao esforço das populações mediterrâneas em conquistar as vias terrestres desde o oceano até o oriental. Aqui está o ponto mais fraco na faixa das civilizações antigas, porque o istmo de Suez dividia o poder marítimo em oriental e ocidental e os desertos áridos da Pérsia, que avançando da Ásia central para o golfo Pérsico ofereciam constantes oportunidades para os poderes nômades de chegar à beira do oceano, dividindo a Índia e a China de um lado e o mundo mediterrâneo de outro. Enquanto os oásis babilônicos, sírios e egípcios eram fragilmente mantidos, os povos das estepes podiam tratar os planaltos abertos do Irã e Ásia menor como os postos avançados de onde podiam atacar a Índia através do Punjab, o Egito através da Síria e a Hungria passando pela ponte quebrada do Bósforo e do Dardanelos. Viena estava na porta da Europa interior sofrendo os ataques do nômades, tanto os que vinham da estrada direta que era a estepe russa, como os que davam uma volta pelo sul dos mares Negro e Cáspio.

Aqui nós temos ilustrada a diferença essencial entre os controles sarracenos e turcos sobre o Oriente Próximo. Os sarracenos eram um ramo da raça semítica, essencialmente povos do Eufrates e do Nilo e dos oásis menores da Ásia inferior. Eles criaram um grande império aproveitando-se dos dois meios de mobilidade permitidos por suas terras - aquele dos cavalos e dos camelo, por um lado, e o dos barcos, por outro lado. Em diferentes épocas, suas frotas controlaram o Mediterrâneo até a Espanha e o oceano Índico até as ilhas de malaias. Desde sua posição central estratégica entre os oceanos a leste 
e a oeste, tentaram a conquista de todas as terras marginais do Velho Mundo, imitando Alexandre e antecipando Napoleão. Poderiam até ameaçar as terras de estepe. Totalmente distintos tanto da Arábia, quanto da Europa, Índia e China, eram os turanianos pagãos vindos do coração fechado da Ásia - os turcos que destruíram a civilização sarracena.

A mobilidade sobre o oceano é a rival natural da mobilidade sobre o cavalo e o camelo no coração do continente. Foi sobre a navegação de rios oceânicos que se baseou o estágio fluvial da civilização, aquele da China sobre o Yangtzé, da Índia sobre o Ganges, da Babilônia sobre o Eufrates, do Egito sobre o Nilo. Foi essencialmente sobre a navegação do Mediterrâneo que se baseou o que se tem descrito como estágio talassocrático da civilização, tanto dos Gregos como dos Romanos. Os sarracenos e os vikings mantinham seu domínio através da navegação das costas oceânicas.

$O$ resultado mais importante da descoberta da rota do cabo da Boa Esperança para as Índias foi conectar as costas de navegação leste e oeste da Eurásia, ainda que através de uma rota circular, e em certa medida neutralizou a vantagem estratégica da posição central que mantinham os nômades das estepes, ao pressioná-los pela retaguarda. A revolução começada pelos grandes marinheiros da geração Colombina dotou a cristandade da mobilidade de poder mais ampla possível, com exceção da mobilidade das asas. O oceano único e contínuo que envolve as terras divididas e insulares é, por certo, a condição geográfica fundamental de união para o comando do mar, e para toda a teoria das modernas estratégia e política navais, tal como expostas por escritores como o Capitão Mahan e o Sr. Spencer Wilkinson. O vasto efeito político que isso produziu foi inverter as relações entre Europa e Ásia, porque na Idade Média a Europa estava encerrada entre um deserto intransponível ao sul, um oceano desconhecido a oeste, vastidões geladas ou cobertas de florestas ao norte e a nordeste, e ao leste e a sudeste era constantemente ameaçada pela mobilidade muito superior dos homens montados em cavalos e camelos. Agora a Europa surgia para o mundo, multiplicando mais de trinta vezes a superfície marinha e as terras costeiras a que ela tinha acesso, e envolvendo com sua influência o poder terrestre eurasiático que até então havia lhe ameaçado a própria existência. Novas Europas foram criadas nas terras desocupadas descobertas no meio das águas, e o que a Grã-Bretanha e a Escandinávia eram para a Europa nos primeiros tempos, a América, a Austrália e em certa medida até a África transsaariana passaram a ser para a Eurásia. Grã-Bretanha, Canadá, os Estados Unidos, África do Sul, Austrália e Japão constituem agora um anel de bases exteriores e insulares para o poder marítimo e o comércio, inacessíveis para o poder terrestre da Eurásia.

Mas o poder terrestre ainda sobrevive, e eventos recentes têm aumentados outra vez sua seu significado. Enquanto os povos marítimos da Europa Ocidental cobriram o oceano com suas frotas, colonizaram os continentes exteriores, e em graus variados fizeram as margens oceânicas da Ásia tributárias suas, a Rússia organizou os cossacos e, emergindo de suas floretas setentrionais, policiou as estepes ao assentar ali seus próprios nômades em combate com os nômades tártaros. O século de Tudor, que assistiu à expansão da Europa Ocidental sobre o mar, também viu o poder russo ser carregado de Moscou para toda a Sibéria. A arremetida rumo ao leste, por parte dos cavaleiros através da Ásia foi um evento quase tão fértil de consequências quanto foi o contorno do Cabo da Boa Esperança, ainda que os dois movimentos tenham se mantido separados um do outro por um longo tempo.

Provavelmente seja uma das mais notáveis coincidências da história que as expansões da Europa sobre o mar e sobre a terra tenham, em certo sentido, continuado a antiga oposição entre Romanos e Gregos. Poucos fracassos tiveram consequências de maior alcance do que o fracasso de Roma em latinizar os gregos. Os teutões foram civilizados e cristianizados pelos romanos, os eslavos principalmente pelos gregos. Foram os romano-teutões que, nas épocas mais recentes, embarcaram rumo ao oceano; foram os grecoeslavos os que cavalgaram sobre as estepes, conquistando os turanianos. Deste modo o poder terrestre moderno difere do poder marítimo não menos na fonte de seus ideais do que nas condições materiais de sua Mobilidade ${ }^{2}$. 
Seguindo a emergência dos cossacos, a Rússia emergiu em segurança de sua anterior reclusão nas florestas setentrionais. Talvez a mudança de maior importância intrínseca que teve lugar na Europa no último século tenha sido a migração dos camponeses russos em direção ao sul, tal que, considerando que as colônias agrícolas anteriormente terminavam nas fronteiras da floresta, o centro da população de toda a Rússia europeia agora reside ao sul dessa fronteira, no meio dos campos de trigo que substituíram as estepes mais a oeste. Odessa ascendeu aqui em importância com a rapidez de uma cidade americana.

Uma geração atrás, o vapor e o canal de Suez pareceram ter aumentado a mobilidade do poder marítimo relativamente ao poder terrestre. As ferrovias atuaram principalmente como alimentadores do comércio oceânico. Mas as ferrovias transcontinentais estão agora transmudando as condições do poder terrestre, e em nenhum lugar podem elas exercer um tamanho efeito como no fechado heart-land da Eurásia, em vastas áreas em que nem madeira nem pedras acessíveis estavam disponíveis para a construção de estradas. Ferrovias desempenham um trabalho grandioso nas estepes porque substituem diretamente a mobilidade dos cavalos e dos camelos, tendo-se ali pulado por cima do estágio de desenvolvimento baseado nas estradas.

No que se refere ao comércio, não se pode esquecer que o tráfego oceânico, porquanto relativamente barato, usualmente envolve quádrupla manipulação das mercadorias - na fábrica de origem, no cais de exportação, no cais de importação e no armazém em terra firme para distribuição pormenorizada; enquanto o vagão da ferrovia continental pode percorrer direto da fábrica exportadora para o armazém importador. Assim, o comércio feito nas margens do oceano tende, mantido o resto constante, a formar a zona de penetração em volta dos continentes, cujo limite interior é marcado aproximadamente pela linha ao longo da qual o custo de quatro manipulações da mercadoria, do frete marítimo e do frete ferroviário desde a costa é equivalente ao custo de duas manipulações e do frete da ferrovia continental. Dizem que os carvões ingleses e alemães competem nesses termos a caminho da Lombárdia.

As ferrovias russas têm um percurso livre de 9600 quilômetros desde Wirballen no oeste até Vladivostok no leste. $O$ exército russo na Manchúria é uma evidência tão significativa da mobilidade do poder terrestre quanto o exército britânico no sul da África o era do poder marítimo. Verdade que a ferrovia Transiberiana é ainda uma única e precária linha de comunicação, mas não terá transcorrida grande parte do século até que toda Ásia esteja coberta de ferrovias. Os espaços dentro do Império Russo e da Mongólia são tão vastos, e suas potencialidades em termos de população, trigo, algodão, combustível e metais são tão incalculavelmente grandes, que é inevitável que um vasto mundo econômico, mais ou menos à parte, irá desenvolver-se inacessível ao comércio oceânico.

À medida que consideramos esta rápida revisão das correntes mais amplas de história, não se torna evidente uma certa persistência da relação geográfica? Não é a região pivô da política mundial essa extensa zona da Eurásia que é inacessível às embarcações, mas que na antiguidade estava aberta aos cavaleiros nômades e hoje está prestes a ser coberta por uma rede de ferrovias? Existiam e existem ali condições de mobilidade de poder militar e econômico de caráter de longo alcance, ainda que limitado. A Rússia substitui o Império Mongol. Sua pressão sobre a Finlândia, sobre a Escandinávia, sobre a Polônia, a Turquia, a Pérsia, a Índia e a China, substitui as investidas centrífugas dos homens das estepes. No mundo todo, ela ocupa a mesma posição estratégica central que a Alemanha ocupa na Europa. Pode atacar por todos os lados e pode também ser atacada por todos os lados, exceto ao norte. O completo desenvolvimento de sua moderna mobilidade ferroviária é uma mera questão de tempo. Nem é provável que alguma possível revolução social irá alterar suas relações essenciais com os grandes limites geográficos de sua existência. Sabiamente reconhecendo os limites fundamentais de seu poder, seus dirigentes desfizeram-se do Alasca, uma vez que não possuir nada no além- mar é para a política russa uma lei tão fundamental como para a Grã-Bretanha é manter a supremacia do oceano. 


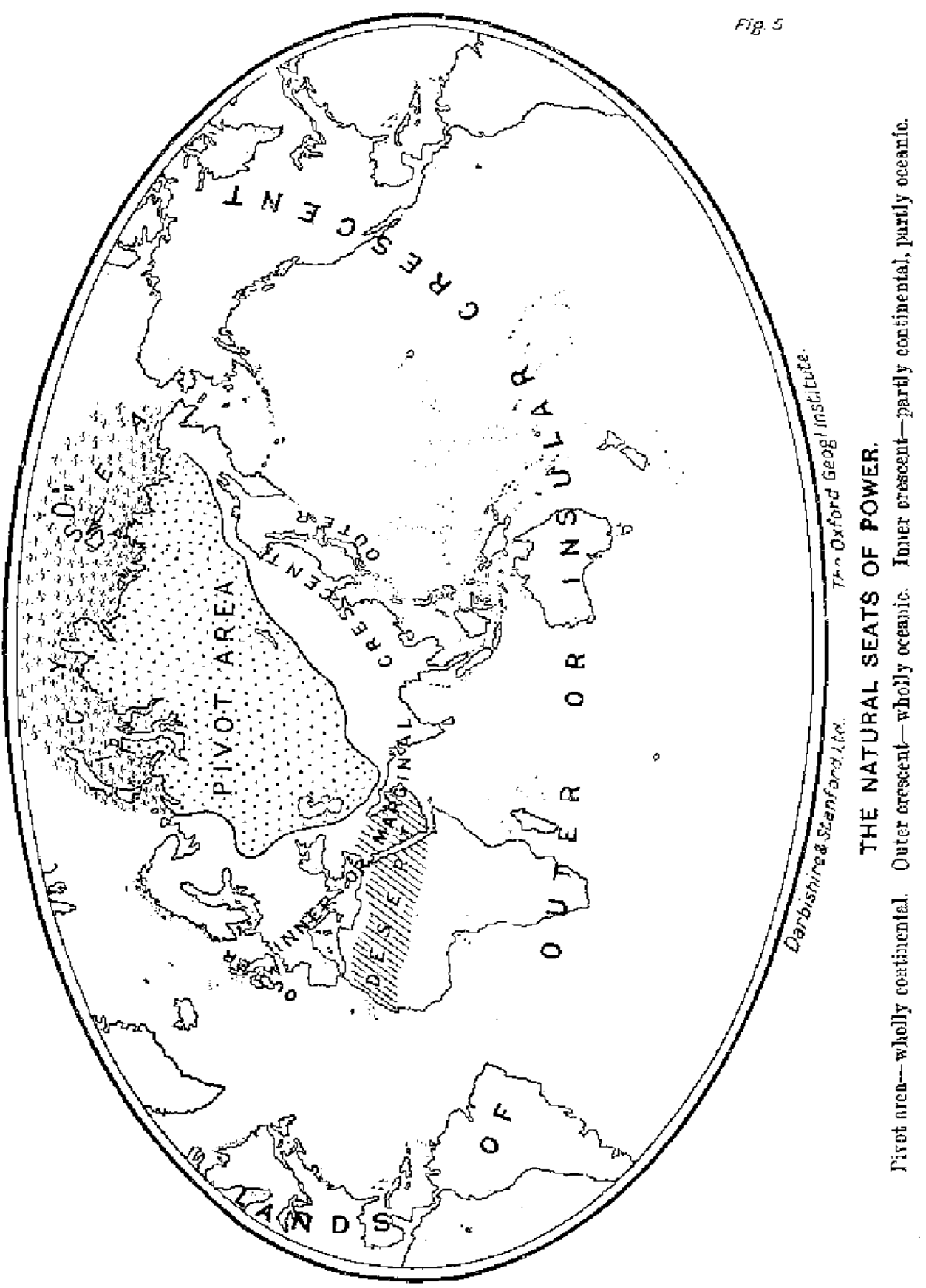


Fora da zona pivô, em um grande arco interior, estão a Alemanha, a Áustria, a Turquia, a Índia e a China, e em um arco exterior, GrãBretanha, África do Sul, Austrália, os Estados Unidos, Canadá e Japão. Nas atuais condições de equilíbrio de poder, o Estado pivô, Rússia, não é equivalente aos Estados periféricos, e poderia criarse um contrapeso na França. Os Estados Unidos recentemente tornaram-se uma potência oriental, afetando o equilíbrio europeu não diretamente, mas através da Rússia, e irão construir o canal do Panamá para tornar seus recursos do Mississipi e do Atlântico disponíveis no Pacífico. Desse ponto de vista, a divisão real entre leste e oeste será encontrada no oceano Atlântico.

A reviravolta do equilíbrio de poder em favor do Estado pivô, resultando em sua expansão sobre as terras marginais da Eurásia, permitiria o uso de vastos recursos continentais para a construção de frotas navais, e o império mundial estaria à vista. Isso poderia acontecer se a Alemanha se aliasse à Rússia. A ameaça de um tal evento poderia, consequentemente, jogar a França dentro de uma aliança com potências marítimas, e França, Itália, Egito, Índia e Coreia tornar-se-iam várias cabeças de ponte onde marinhas estrangeiras poderiam apoiar exércitos para compelir os aliados pivôs a prepararem forças terrestres, prevenindo-os de concentrar toda sua força em embarcações. Em uma escala menor, isso é o que conseguiu fazer Wellington em sua base marítima de Torres Vedra durante a Guerra Peninsular. Não poderia mostrarse ser essa, no fim, a função estratégica da Índia no sistema imperial britânico? Não é essa a ideia subjacente à concepção do Sr. Amery de que a frente militar britânica se estende do Cabo até o Japão, através da Índia?

O desenvolvimento das vastas potencialidades da América do Sul pode ter uma influencia decisiva no sistema. Podem fortalecer aos Estados Unidos ou, pelo contrário, se a Alemanha pudesse desafiar com sucesso a doutrina Monroe, poderia separar Berlim do que talvez possa descrever como política de pivô. As combinações particulares de poder que estão em equilíbrio não são materiais; minha argumentação é que de um ponto de vista geográfico elas provavelmente rodarão ao redor do Estado pivô, que provavelmente há de ser sempre grande mas com uma limitada mobilidade se comparado com as potências marginais e insulares que o rodeiam.

Falei como um geógrafo. O equilíbrio real do poder político em um dado momento é, por certo, o produto de condições geografias tanto econômicas como estratégicas, por um lado, e do número relativo, virilidade, equipamento e organização dos povos competidores, por outro. $\mathrm{Na}$ mesma proporção em que se tenham estimado com precisão essas quantidades, teremos possibilidade de ajustar diferenças sem o bruto recurso às armas. E as quantidades geográficas nesse cálculo são mais mensuráveis e mais próximas a serem constantes do que as humanas. Em consequência, podemos esperar que nossa fórmula se aplique igualmente à história passada e à política atual. Os movimentos sociais de todos os tempos desenvolveram-se essencialmente ao redor das mesmas características físicas, já que duvido que o progressivo dessecamento da Ásia e da África, mesmo se comprovados, tenham alterado vitalmente o meio humano nas épocas históricas. Considero que a marcha do império para oeste foi uma breve rotação do poder marginal em volta das margens sudoeste e oeste da área pivô. As questão dos Próximo, Médio e Extremo Oriente estão relacionadas ao equilíbrio instável das potências interiores e exteriores naquelas partes do arco marginal onde o poder local é, no presente, mais ou menos insignificante.

Em conclusão, seria correto apontar que a implantação de algum novo controle da área interior, em substituição ao controle da Rússia, não tenderia a reduzir o significado geográfico da posição pivô. Fossem os chineses, por exemplo, organizados pelos japoneses para derrotar o império russo e conquistar seu território, eles poderiam instituir o perigo amarelo para a liberdade do mundo simplesmente porque adicionariam uma frente oceânica aos recursos do grande continente, uma vantagem de que até hoje não puderam gozar os russos ocupantes da região pivô. 


\section{Notas.}

1. Ver The Races of Europe, do Professor W. Z. correta. Mesmo os gregos bizantinos teriam Ripley (Kegan Paul, 1900).

2. Esta afirmação foi criticada na discussão que se seguiu à leitura do paper. Ao reconsiderar o parágrafo, ainda penso que esteja substancialmente sido diferentes caso Roma tivesse completado a subjugação da Grécia antiga. Sem dúvida os ideais de que se fala foram antes bizantinos do que helênicos, mas não eram romanos - o que é o ponto aqui. [nota do autor]. 